Historic, archived document

Do not assume content reflects current scientific knowledge, policies, or practices. 

999.9

United States

Department of Agriculture

Forest Service

Intermountain

Research Station

Research Paper

INT.388

February 1988

Uits
Bracken Fern

Inhibition of Conifer

Regeneration in

Northern Idaho

\author{
Dennis E. Ferguson \\ Raymond J. Boyd
}

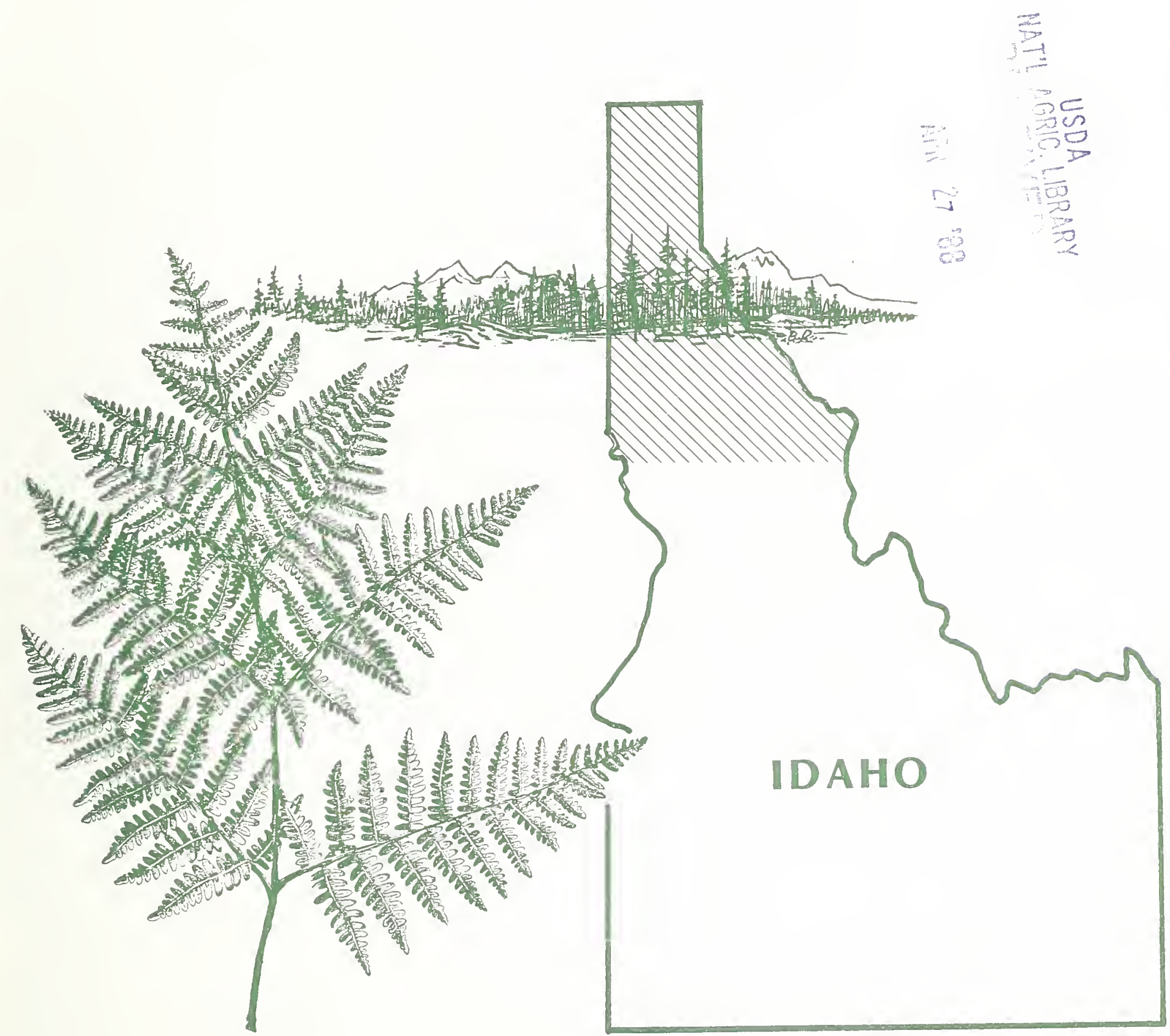




\section{THE AUTHORS}

DENNIS E. FERGUSON is a research forester, Intermountain Research Station, Forestry Sciences Laboratory, Moscow, ID. He has worked primarily with predicting regeneration establishment and growth of young trees and stands in the Northern Rocky Mountains.

RAYMOND J. BOYD is a research forester (retired), Intermountain Research Station, Forestry Sciences Laboratory, Moscow, ID. He has an extensive research background dealing with regenerating and managing young stands.

\section{RESEARCH SUMMARY}

Results of investigations on allelopathy of bracken fern in northern Idaho are reported. The study objective was to gain an understanding of how bracken fern interferes with establishment of conifers and shrubs, often to their complete exclusion.

Containerized conifer seedlings grown in pots of soil from a bracken fern glade grew less than seedlings grown in pots of forest soil or potting mix. Mortality was minimal. In greenhouse tests, bracken soil had little effect on germination of conifer and shrub seeds. Although statistically significant differences were found in germination and growth of shrub species, the differences are not significant in a practical sense because sufficient seed of all species became established and grew in greenhouse conditions. Five soil depths were also tested to determine the depth to which phytotoxins might be effective in preventing seedling establishment. Only the $0-$ to $5-\mathrm{cm}$ layer of bracken soil decreased germination and growth of shrub species.

Additional testing was conducted under field conditions. Conifer seed was stratified over the winter on soils in bracken glades and on potting mix transported to the site. In the spring, seeds germinated well on both soil types, but most seeds germinating on bracken soil died. Radicles were long, indicating adequate germination energy, but germinates died before shedding seedcoats. Radicles were dark brown to black in color. Seeds that germinated on potting mix were healthy and shed their seedcoats, but some radicle tips were slightly discolored.

Death of germinants in this study probably resulted from absorption of bracken phytotoxins that have accumulated in the soil over a number of years. Phytotoxins are thought to be concentrated in a thin layer near the soil surface. Allelopathy tests should be conducted under field conditions because transporting, mixing, or drying the soil can reduce the effect of phytotoxins bound in the soil complex. 


\title{
Bracken Fern Inhibition of Conifer Regeneration in Northern Idaho
}

\author{
Dennis E. Ferguson \\ Raymond J. Boyd
}

\section{INTRODUCTION}

Bracken fern (Pteridium aquilinum [L.] Kuhn) is the most widely distributed vascular plant in the world (Page 1982), and Taylor (1985) calls bracken the most successful international weed of the 20 th century. It is a highly competitive species in grazing areas and disturbed woodlands. Invasion can be through spore germination or expansion of rhizomes. Bracken's success has been attributed to its ability to compete for moisture, nutrients, and light, smothering of other plants by senescing fronds, unpalatability of bracken to animals and insects, lack of disease problems, a rhizome system that readily sprouts following disturbance, and chemical interference with other plants (allelopathy).

In northern Idaho, bracken fern can be a vigorous competitor in forests and pastures. Bracken also occupies 1/5- to 6 -ha glades where woody vegetation is virtually excluded and only a few forb and grass species grow. The absence of woody species and charcoal fragments in glade soils suggests bracken has been dominant for perhaps hundreds of years.

Phytotoxins released by bracken fern can inhibit the establishment and growth of associated species. The allelopathic effect of bracken has been reported in other parts of the world and could be a factor operating in bracken-dominated areas of northern Idaho. We conducted investigations to test the allelopathic potential of bracken fern in northern Idaho and gain an understanding of the mechanism(s) causing regeneration failures.

\section{LITERATURE REVIEW}

Bracken fern is a widely distributed weed species, causing problems in places such as Africa, India, Australia, New Zealand, North America, South America, and the British Isles (Cody and Crompton 1975; Gliessman 1976). Published information on bracken is quite extensive, and excellent review articles are available (Braid 1959; Cody and Crompton 1975). Increases in abundance of bracken are correlated with clearing of farm and forest by man (Page 1982; Rymer 1976). Bracken has a cumulative toxic effect on livestock (Cody and Crompton 1975; Cooper-Driver 1976) and is linked to cancer in humans (Evans 1976; Hirono 1981; Hirono and others 1972). In addition, studies have shown bracken produces phytotoxins that interfere with establishment and growth of other plants.

Bracken fern is usually a minor component of native forests but increases with disturbance by fire, harvesting, or grazing. Windblown spores disperse bracken over long distances, although the main reproductive method is expansion of underground rhizomes. Spores evidently need nearly sterile soil conditions before germination will occur (Cody and Crompton 1975; Page 1982). Cody and Crompton (1975) note that there are no published reports of spores germinating under natural conditions in Canada. Sporelings have been observed in Britain and elsewhere, but not in abundance.

Bracken fern's extensive rhizome system spreads rapidly. Conway (1952) grew a young plant in a trough to document vegetative reproduction. Forty-five fronds were produced the second growing season, 136 the third, and 297 the fourth season. Znerold (1979) calculated frond density of 286,300 stems/ha at a bracken glade in northern Idaho,

About one-fifth of the underground buds produce fronds in the spring. Dormant buds provide a reservoir of potential fronds to replace those killed by frost, fire, or other agents. The deep rhizome system is impervious to most damaging agents and readily resprouts.

Disturbances favor bracken fern over associated species. Bracken is difficult to control and nearly impossible to eradicate. The best long-term control is by repeated cuttings, cultivation, or herbicides (Martin 1976; Preest 1975). Herbicides are probably the most effective method of control because the rhizomes are killed.

Livestock have been used to control bracken, but they do not prefer bracken as a food source. Bracken is toxic to livestock if eaten for several weeks or months. Poisoning, which has been frequently documented, affects cattle, horses, and sheep differently (Hirono 1981). Pamukcu and others (1978) have shown that the milk of cows fed bracken fern has toxic, carcinogenic, and mutagenic properties.

Bracken fern also gains a competitive advantage over other plants through chemical interference. Allelopathic compounds in many plants, including bracken, are thought to be metabolic byproducts that have accumulated in the plant and are often stored in localized plant parts such as vacuoles and cell walls (DeBell 1970; Fisher 1979; Whittaker and Feeny 1971). Leaching and decomposition release phytotoxins into the environment. Microbial action breaks chemicals down into secondary plant chemicals, which are also potential phytotoxins.

Rice $(1979,1984)$ reviews the subject of allelopathy and discusses bracken and other ferns. The remainder of this review discusses the allelopathic potential of bracken.

Gliessman and Muller (1972) demonstrated that water leachate from bracken fronds reduces radicle growth of 
brome grass (Bromus rigidus). Dead fronds collected before fall rains were the most toxic. Average 48-hour radicle length of seed soaked 2 hours in bracken leachate was 82.2 percent of the control groups. Quadrupling the leachate concentration decreased radicle elongation to 31.4 percent of the control. Leachate from green fronds was not toxic; yellowing fronds were toxic only at concentrated levels. Leachate did not reduce germination of the brome grass, but wild oat (Avena fatua) germination was reduced to 76 percent of the control.

Gliessman and Muller (1978) also reported on experiments excluding other factors thought to be responsible for bracken's dominance. Eliminated were animals, soil differences, and competition for light, moisture, and nutrients. These factors account for some differences between bracken-dominated land and adjacent grasslands but were not the major reasons for the differences. They conclude that allelopathy, in the form of water-soluble phytotoxins from dead fronds, is the primary mechanism accounting for bracken dominance.

A few studies have reported on allelopathic effects of bracken on conifers. Stewart (1975) found that extracts from senescent bracken fronds did not reduce germination of Douglas-fir (Pseudotsuga menziesii) but did reduce germination of western thimbleberry (Rubus parviflorus) and delayed germination of salmonberry (Rubus spectabilis). In Stewart's study, seeds moistened with either distilled water or bracken leachate were stratified in vermiculite and germinated on sterile pumice.

In a corresponding greenhouse experiment, Stewart germinated seeds on untreated forest soil, on forest soil with seeds covered by bracken frond material, and on forest soil in which bracken frond material was mixed with the soil. When seeds were covered by bracken, germination of Douglas-fir was 58 percent versus 65 percent for untreated soil. Germination of salmonberry and thimbleberry was also reduced in pots having seeds covered by bracken ( 2 percent germination for salmonberry versus 14 percent in the control and 29 percent germination for thimbleberry versus 65 percent in the control). Shoot length and dry weight of thimbleberry seedlings were reduced in pots where bracken was mixed with the soil.

Del Moral and Cates (1971) showed that water extracts from bracken fern reduced growth of Douglas-fir, but the effect was barely significant. Results are not conclusive in this instance because green frond material was used, which Gliessman and Muller (1972) later found to be nontoxic.

Seedlings have been successfully planted in cutover forests dominated by bracken fern. Dimock (1964) reported 79 percent survival of Douglas-fir seedlings planted on a productive site in western Washington. But growth was extremely slow, with trees averaging only $29.5 \mathrm{~cm}$ tall after four growing seasons. A planting study by Boyd and Znerold (in preparation) was confounded by high losses of planted trees to pocket gophers (Thomomys sp.). Survival after 7 years was only 15 percent, leaving 463 trees available for height measurement. Heights of trees planted in plots where bracken had been eliminated were nearly twice the heights of trees growing in brackendominated plots.
Allelopathic effects can also be indirect. Chemicals released by plants could stimulate harmful microorganisms or suppress helpful ones (Rice 1979). The relationship between bracken fern and beneficial mycorrhizal fungi has been explored. Acsai and Largent (1983) found no effect of bracken phytotoxins on ectomycorrhizae formation with white fir (Abies concolor) or Douglas-fir in northern California. Rose and others (1983) found mixed effects during in vitro studies on growth of four mycorrhizal fungi. One fungus was stimulated, two were inhibited, and the other was not affected.

Buildup of phytotoxins in the soil depends on the amount produced, the rate at which the compounds are deactivated, and soil characteristics (Rice 1979). Phytotoxic effects seem most pronounced in soils that are heavy in texture, poorly aerated, moist a good portion of the year, and often cool in temperature (DeBell 1970; Fisher 1978; Horsley 1977; Rietveld and others 1983). For example, Rietveld and others felt that juglone from black walnut (Juglans nigra) was not harmful until the walnut trees were large enough to produce substantial amounts which, in combination with wet soils that reduced microbial activity, allowed juglone to accumulate in the soil.

Phenolic acids have been identified as the most probable cause of bracken's allelopathic effect. Phenolic acids are water soluble and thus able to leach from fronds into the soil. Cinnamic and benzoic acids are the two most frequently mentioned phenolic acids associated with bracken. Derivatives of cinnamic acid include $p$-coumaric acid, caffeic acid, and ferulic acid while derivatives of benzoic acid include $p$-hydroxybenzoic acid, vanillic acid, and protocatechuic acid (Bohm and Tryon 1967; Glass and Bohm 1969; Whitehead 1964).

Many studies show a statistically significant reduction in germination or growth attributable to bracken fern allelopathy, but the magnitude of these results does not demonstrate how woody species could be virtually eliminated from bracken glades in northern Idaho. When one considers seedfall from species adjacent to bracken glades, éven a low percentage germination should result in higher coverage of these species over time.

Some light has been shed on the reason for differences between field observations and results of greenhouse and laboratory tests. Moving, drying, or mixing the soil may result in detoxification of plant residues. Microbial activity might be altered by changes in the temperature or moisture regime of the soil; and if the soil is mixed, allelopathic chemicals might be diluted. Brown (1967) suggests that soil compounds quickly break down once the soil is removed from the field site to the greenhouse. Fisher (1978) found that soil containing juglone was detoxified if allowed to dry before bioassay tests were started, whereas the inhibitory effects remained strong when the soil was not dried. 


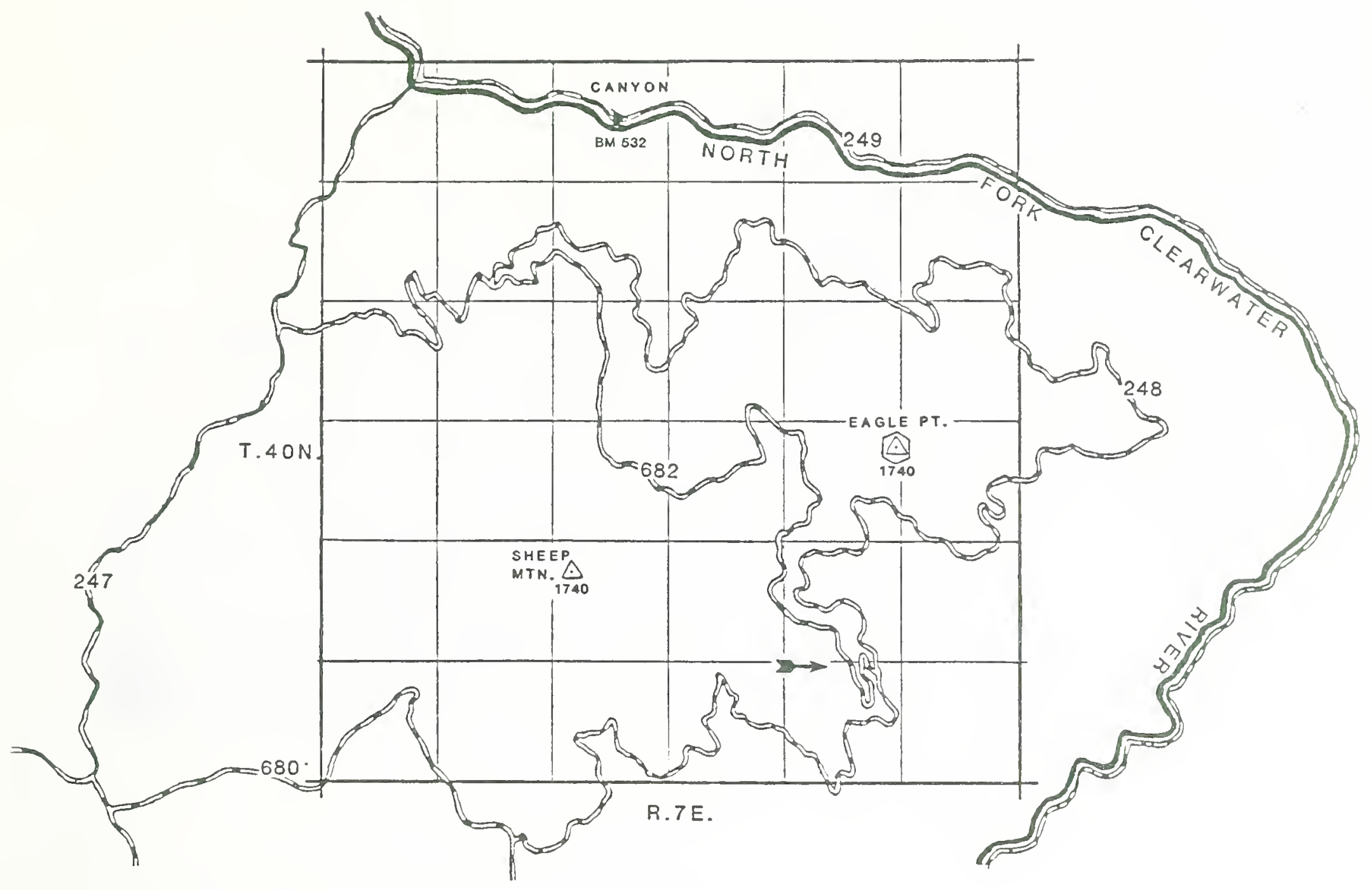

Figure 1-Eagle Point study area (arrow) on the North Fork Ranger District.

\section{EAGLE POINT STUDY SITE}

Research was conducted in and near bracken glades south of Eagle Point on the North Fork Ranger District of the Clearwater National Forest (figs. 1 and 2). Elevation of the site averages $1,430 \mathrm{~m}$ above sea level. Aspect is easterly, with slope angles of 20 to 50 percent. The most prevalent habitat type is Abies grandis/Asarum caudatum (grand fir/wild ginger) as described by Cooper and others (1987).

Soils are dark brown to black silt loams (Wilson and others 1983). The dark-colored umbric soil surface layer is loessal material influenced by ash from Mount Mazama (Crater Lake). Also characteristic of the area is a high organic turnover rate in the soil (similar to prairie grasslands), deep snowpacks during the winter, and areas with high water tables, at least during a portion of the year.

Several bracken glades existed prior to harvesting adjacent forests (fig. 3). Within the glades, there is scant evidence of past or present woody vegetation; neither buried wood nor charcoal fragments are found. Herbacenus species other than bracken include glacier-lily (Erythronium grandiflorum), larkspur (Delphinium sp.), starwort (Stellaria obtusa), coneflower (Rudbeckia occidentalis), and occasional wild ginger, sedges (Carex sp.), and grasses.
In the harvested areas, coverage by bracken fern has expanded, and these areas now contain a mixture of bracken, shrubs, forbs, grasses, and some conifer regeneration. The study site has been planted several times without success, not only because of bracken fern but also high populations of pocket gophers and big game use.

Natural regeneration has become established mainly along skid trails and roads.

Portions of the study site were treated in 1977 with the herbicide asulam to test control effectiveness and performance of planted conifers (Boyd and Znerold in preparation; Znerold 1979). Bracken control was excellent, but pocket gopher and big game damage confounded the planting trials. The sprayed areas now support more grasses, sedges, and forbs than unsprayed controls, but bracken is reinvading and frond density is nearly the same as before spraying. Sprayed areas are used as one treatment in this study. 


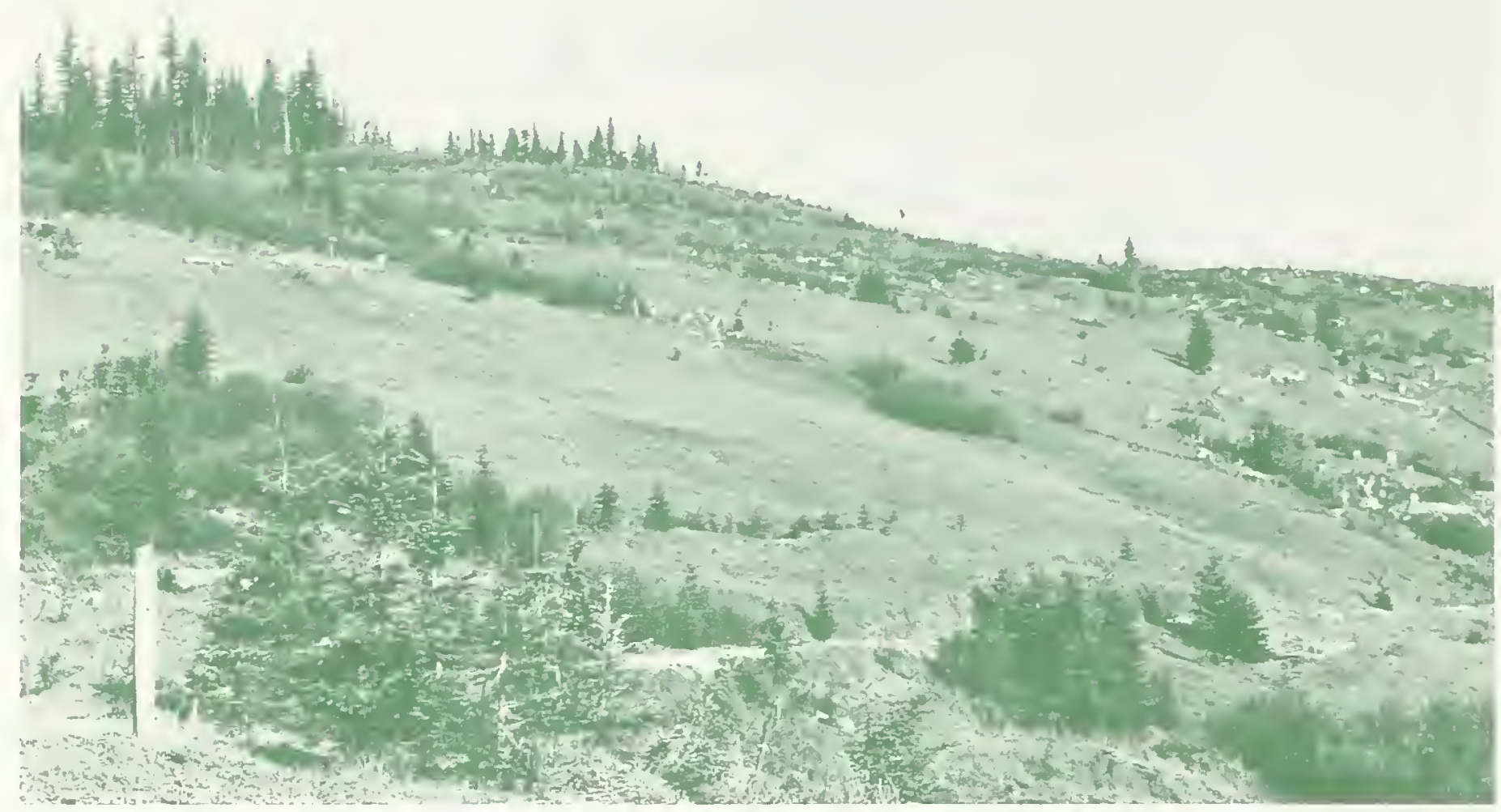

Figure 2-View of cutover area showing intermixing of bracken, stumps, and brush.
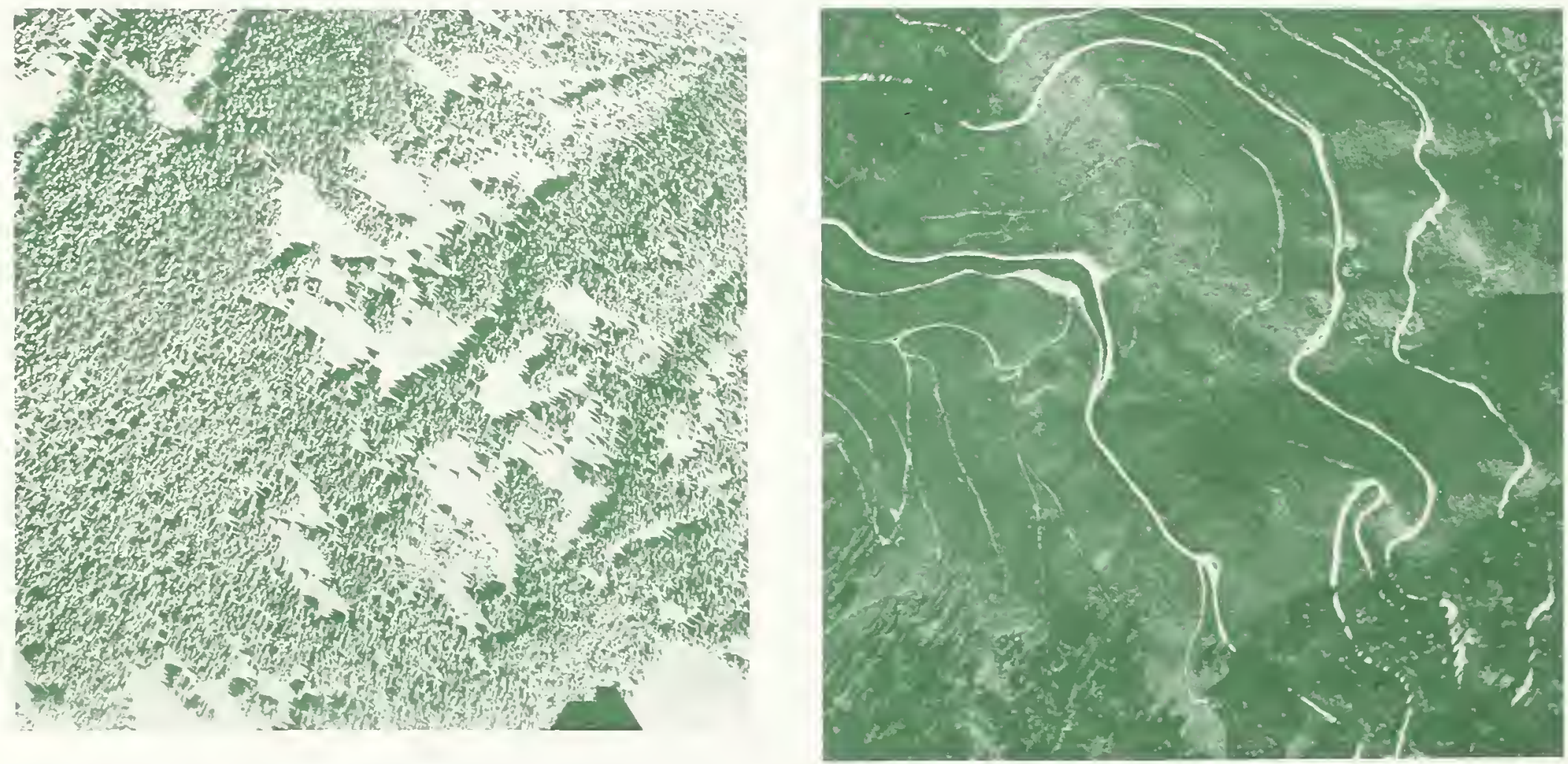

Figure 3- Aerial view of Eagle Point study site in 1956 (left) and 1981 (right). 


\section{PLANTING STUDY}

\section{Procedures}

In the spring of 1984 , soil was collected at Eagle Point and placed in 1.9-liter pots. The four treatments were bracken glade, bracken glade sprayed in 1977 (Znerold 1979), adjacent forest, and forestry potting mix (1:1 ratio of peat and vermiculite). Five replications were sampled in each treatment, with 10 soil samples taken from each replicate, for a total of 200 pots. The soil was lifted intact by pushing a hollow metal cylinder into the ground, clamping onto the sample, lifting it out, and placing it into the pot.

Pots were randomly arranged by replication in a shadehouse (50 percent reduction in light) in Moscow, ID. Two container-grown seedlings were planted in each pot-one Douglas-fir and one grand fir in the first 100 pots, and two Engelmann spruce (Picea engelmannii) in each of the other 100 pots. Plastic fruit container lids were sealed, inverted, and placed under individual pots to provide a reservoir of water, reduce leaching, and prevent transfer of leachates among pots.

Seedlings were grown for two summers. Fresh bracken fern litter was not added between growing seasons. At the end of the second summer, seedlings were measured for second-year height growth and total green top weight.

\section{Results}

Few seedlings died-four grand fir and two spruce. But tops or branches sometimes died in the bracken treatments. Eighteen trees had tops or branches that were dead; of these, 14 trees were from one of the bracken fern treatment soils.

Height growth during the second year and total green top weight were chosen to test treatment differences. Grow th the year of planting is largely a function of predetermined buds while growth the second year reflects conditions experienced by the seedlings since planting. Total green top weight was recorded as an expression of biomass production.

Results of analysis of variance are shown in table 1 . The number of trees in each analysis is reduced by the number of dead trees and, in the case of growth, the number of trees with dead tops. Patterns are similar for all three species. Trees in forest and potting mix soils consistently outperform either of the bracken treatments. Trees in the forest soil or potting mix have about 1.8 times the height increment and 1.6 times the top weight of those in the bracken soil treatments. Growth and top weight are consistently lower in the sprayed bracken compared to the unsprayed, but this difference is not significant in most of the comparisons.

Treatment differences may be conservative in that litter was not added between the two growing seasons and the soil plug around the roots of container-grown seedlings provided a reserve of soil not influenced by bracken fern. Long-term effects on mortality are unknown because, in natural conditions, conifer roots may contact bracken rhizomes or residues from decomposing fronds.

\section{BIOASSAY STUDY}

\section{Procedures}

This study was conducted in conjunction with the planting study just described. The objective was to determine if bracken soil reduced germination and growth of woody species and, if so, how far into the soil might the phytotoxins be effective.

Three native soil treatments were used: bracken glade, sprayed bracken glade, and adjacent forest. Five soil pits per treatment were dug to a depth of $60 \mathrm{~cm}$ or to soil parent material, whichever was deeper. Six soil samples were collected from each pit at levels of 0 to $5 \mathrm{~cm}, 13$ to $18 \mathrm{~cm}, 28$ to $33 \mathrm{~cm}, 43$ to $48 \mathrm{~cm}, 60$ to $90 \mathrm{~cm}$, and a mixture of the five levels. Soil was transported in plastic bags to the Moscow laboratory.

Seeds of eight species were sown in this test: Douglasfir, grand fir, Engelmann spruce, subalpine fir (Abies lasiocarpa), Rocky Mountain maple (Acer glabrum), huckleberry (Vaccinium globulare), Sitka alder (Alnus sinuata), and chokecherry (Prunus virginiana). Seeds were sown in 1-liter pots, with 2 species per pot, 25 seeds per species. Thus, the study design is 3 treatments $\times 5$ replications $\times$ 6 depths $\times 8$ species $\times 25$ seeds per species, for a total of 18,000 seeds. Conifer seed was not stratified, but shrub seed had been stratified by a local nursery specializing in growing native plants.

Table 1-Planting study: containerized seedling mean 1985 height increment (growth) and total green top weight (top weight) by treatment and species. Within column, means followed by different letters are significantly different at the 5 percent level, using Duncan's multiple range test

\begin{tabular}{|c|c|c|c|c|c|c|}
\hline \multirow[b]{2}{*}{ Treatment } & \multicolumn{2}{|c|}{ Douglas-fir } & \multicolumn{2}{|c|}{ Grand fir } & \multicolumn{2}{|c|}{ Spruce } \\
\hline & Growth & $\begin{array}{c}\text { Top } \\
\text { weight }\end{array}$ & Growth & $\begin{array}{c}\text { Top } \\
\text { weight }\end{array}$ & Growth & $\begin{array}{l}\text { Top } \\
\text { weight }\end{array}$ \\
\hline & $m m$ & $g$ & $m m$ & $g$ & $m m$ & $g$ \\
\hline Bracken & $35.4^{b}$ & $117.3^{c}$ & $32.2^{b, c}$ & $109.8^{b}$ & $19.3^{b}$ & $25.3^{b}$ \\
\hline Sprayed & $31.4^{b}$ & $91.0^{c}$ & $19.9^{c}$ & $78.1^{c}$ & $16.9^{b}$ & $24.1^{\mathrm{b}}$ \\
\hline Forested & $57.3^{a}$ & $155.6^{\mathrm{b}}$ & $49.9^{a}$ & $129.9^{b}$ & $32.6^{a}$ & $38.5^{\mathrm{a}}$ \\
\hline Potting mix & $68.3^{a}$ & $266.4^{a}$ & $38.9^{a, b}$ & $160.1^{a}$ & $29.1^{\mathrm{a}}$ & $32.3^{a}$ \\
\hline No. of trees & 92 & 100 & 93 & 96 & 198 & 198 \\
\hline
\end{tabular}


Table 2-Bioassay study: percentage germination and results of analysis of variance by species, treatment, and soil depth. Each figure is the average of five replicates of 25 seeds. Within species and column, means followed by different letters are significantly different at the 5 percent level, using Duncan's multiple range test

\begin{tabular}{|c|c|c|c|c|c|c|c|}
\hline \multirow[b]{2}{*}{ Species } & \multirow[b]{2}{*}{ Treatment } & \multicolumn{6}{|c|}{ Soil depth, cm } \\
\hline & & 0.5 & $13-18$ & $28-33$ & $43-48$ & 60.90 & Mixed \\
\hline & & $\ldots$ & $\ldots$. & Sermina & percer & $\ldots$. & $\ldots$. \\
\hline \multirow[t]{3}{*}{ Huckleberry } & Bracken & $17.6^{a, b}$ & $28.0^{\mathrm{a}}$ & $45.6^{a}$ & $52.0^{\mathrm{a}}$ & $61.6^{\mathrm{a}}$ & $32.8^{a, b}$ \\
\hline & Sprayed & $9.6^{\mathrm{b}}$ & $26.4^{\mathrm{a}}$ & $53.6^{\mathrm{a}}$ & $54.4^{a}$ & $55.2^{a}$ & $9.6^{b}$ \\
\hline & Forested & $28.0^{\mathrm{a}}$ & $31.2^{\mathrm{a}}$ & $35.2^{a}$ & $57.6^{a}$ & $60.0^{\mathrm{a}}$ & $41.6^{\mathrm{a}}$ \\
\hline \multirow[t]{3}{*}{ Alder } & Bracken & $26.4^{\mathrm{b}}$ & $41.6^{\mathrm{a}}$ & $59.2^{\mathrm{a}}$ & $50.4^{\mathrm{a}}$ & $60.0^{a}$ & $57.6^{\mathrm{a}}$ \\
\hline & Sprayed & $28.8^{a, b}$ & $49.6^{a}$ & $62.4^{a}$ & $61.6^{\mathrm{a}}$ & $58.4^{\mathrm{a}}$ & $54.4^{\mathrm{a}}$ \\
\hline & Forested & $45.6^{\mathrm{a}}$ & $48.8^{a}$ & $60.0^{\mathrm{a}}$ & $61.6^{\mathrm{a}}$ & $55.2^{\mathrm{a}}$ & $56.0^{\mathrm{a}}$ \\
\hline \multirow[t]{3}{*}{ Subalpine fir } & Bracken & $53.6^{a}$ & $59.2^{\mathrm{a}}$ & $56.8^{\mathrm{b}}$ & $69.6^{a}$ & $20.0^{b}$ & $36.0^{b}$ \\
\hline & Sprayed & $53.6^{a}$ & $56.0^{\mathrm{a}}$ & $73.6^{a}$ & $60.8^{a}$ & $41.6^{a}$ & $61.6^{\mathrm{a}}$ \\
\hline & Forested & $47.2^{\mathrm{a}}$ & $53.6^{a}$ & $50.4^{b}$ & $42.4^{b}$ & $18.4^{b}$ & $57.6^{a}$ \\
\hline \multirow[t]{3}{*}{ Engelmann spruce } & Bracken & $48.0^{\mathrm{a}}$ & $57.6^{\mathrm{a}}$ & $59.2^{a}$ & $59.2^{\mathrm{a}}$ & $54.4^{\mathrm{a}}$ & $48.8^{\mathrm{a}}$ \\
\hline & Sprayed & $57.6^{\mathrm{a}}$ & $55.2^{\mathrm{a}}$ & $64.0^{\mathrm{a}}$ & $61.6^{\mathrm{a}}$ & $58.4^{a}$ & $50.4^{a}$ \\
\hline & Forested & $54.4^{\mathrm{a}}$ & $59.2^{\mathrm{a}}$ & $62.4^{a}$ & $56.0^{\mathrm{a}}$ & $60.8^{a}$ & $51.2^{\mathrm{a}}$ \\
\hline \multirow[t]{3}{*}{ Douglas-fir } & Bracken & $43.2^{a}$ & $61.6^{a}$ & $57.6^{a}$ & $71.2^{a}$ & $43.0^{a}$ & $55.2^{a}$ \\
\hline & Sprayed & $35.2^{a}$ & $55.2^{\mathrm{a}}$ & $52.0^{\mathrm{a}}$ & $49.6^{b}$ & $43.2^{\mathrm{a}}$ & $49.6^{a}$ \\
\hline & Forested & $25.6^{a}$ & $53.6^{a}$ & $36.8^{a}$ & $52.8^{\mathrm{D}}$ & $31.2^{\mathrm{a}}$ & $58.4^{a}$ \\
\hline \multirow[t]{3}{*}{ Grand fir } & Bracken & $69.6^{a}$ & $82.4^{a}$ & $84.0^{\mathrm{a}}$ & $82.4^{\mathrm{a}}$ & $77.0^{\mathrm{a}}$ & $72.8^{a}$ \\
\hline & Sprayed & $72.8^{a}$ & $80.8^{a}$ & $82.4^{\mathrm{a}}$ & $76.8^{a}$ & $75.2^{\mathrm{a}}$ & $81.6^{a}$ \\
\hline & Forested & $68.8^{a}$ & $80.8^{a}$ & $75.2^{a}$ & $77.6^{\mathrm{a}}$ & $78.4^{\mathrm{a}}$ & $80.0^{\mathrm{a}}$ \\
\hline
\end{tabular}

Seed was sown in late June through early July 1984, covered lightly with grit, and placed in a greenhouse. Watering was from below, using inverted fruit container lids under each pot, and from above using a fine mist to keep seeds moist.

Germination was recorded at regular intervals throughout the summer. Grand fir and Douglas-fir germinated quickly and were thinned to the tallest three trees after germination was essentially complete.

\section{Results}

Two of the eight species, maple and cherry, did not germinate in sufficient numbers to include in the analysis. The seed appeared healthy; most likely the stratification requirements had not been met. Germination of huckleberry and alder was significantly reduced ( 5 percent significance level) in the 0 - to 5 -cm soil depth for both bracken treatments (table 2). Germination of huckleberry was also reduced in the mixed soil. Conifer seed germination was good, and comparisons of treatment means show few significant differences. Certainly, sufficient seed germinated in each treatment to successfully establish these species.

Seedling heights at the end of the first growing season were compared (table 3). For each group of 25 seeds, the tallest three germinants were recorded and averaged. Sometimes only one or two germinants were available. The average height per pot by species was used in an analysis of variance.
There is a trend for huckleberry and alder to be taller in the forest soil treatment for all soil depths. This trend is statistically significant at the 5 percent level in the 0 - to 5 -cm soil depth and the mixed soil. Here, huckleberry and alder in the forest treatment soil are roughly twice as tall as in bracken treatment soil.

Within soil depth, conifers show little difference among treatments. Conifer heights decrease with increasing soil depth, but this trend is not related to treatment.

\section{- SEED STRATIFICATION STUDY}

\section{Procedures}

The planting and greenhouse bioassay tests show that woody species can germinate and grow in soil previously dominated by bracken fern. Further testing needed to be done in natural environments. The next step was to stratify seed at the Eagle Point study site.

Seeds of Douglas-fir, grand fir, Engelmann spruce, and subalpine fir were sown on three native soils and on potting mix transported to the study area. The soils selected were bracken glade, sprayed bracken glade, and adjacent forest. The forest site has a closed canopy overstory in contrast to the open conditions in the bracken sites. The 4 species $\times 3$ treatments $\times 2$ soil types were replicated 6 times, 25 seeds per replicate, for a total of 3,600 seeds.

The potting mix was placed in $10-\mathrm{cm}$ deep aluminum pans. The pans were buried in treatment areas, with the surface of the potting mix level with the soil surface and 
Table 3-Bioassay study: analysis of variance on first-year average height $(\mathrm{mm})$ of the three tallest seedlings for each species, treatment, and soil depth. Each figure is the average of five replicates. Each replicate is represented by the average height of the three tallest seedlings if available; otherwise two or one seedling. Within species and column, means followed by different letters are significantly different at the 5 percent level using Duncan's multiple range test

\begin{tabular}{|c|c|c|c|c|c|c|c|}
\hline \multirow[b]{2}{*}{ Species } & \multirow[b]{2}{*}{ Treatment } & \multicolumn{6}{|c|}{ Soil depth, cm } \\
\hline & & $0-5$ & $13-18$ & $28-33$ & 43.48 & $60-90$ & Mixed \\
\hline & & $\ldots$ & $\ldots$. & Average & ight, $m$ r & $\ldots$. & $\ldots$. \\
\hline \multirow[t]{3}{*}{ Huckleberry } & Bracken & $3.0^{\mathrm{b}}$ & $3.4^{\mathrm{a}}$ & $4.9^{\mathrm{a}}$ & $3.9^{\mathrm{a}}$ & $3.1^{\mathrm{a}}$ & $3.3^{\mathrm{a}, \mathrm{b}}$ \\
\hline & Sprayed & $2.3^{\mathrm{b}}$ & $2.5^{\mathrm{a}}$ & $4.5^{\mathrm{a}}$ & $3.6^{\mathrm{a}}$ & $3.2^{\mathrm{a}}$ & $2.5^{\mathrm{b}}$ \\
\hline & Forested & $6.4^{\mathrm{a}}$ & $4.3^{\mathrm{a}}$ & $4.6^{\mathrm{a}}$ & $4.1^{\mathrm{a}}$ & $4.3^{\mathrm{a}}$ & $7.1^{\mathrm{a}}$ \\
\hline \multirow[t]{3}{*}{ Alder } & Bracken & $11.5^{b}$ & $12.7^{\mathrm{a}, \mathrm{b}}$ & $9.2^{\mathrm{a}}$ & $6.5^{\mathrm{b}}$ & $6.8^{\mathrm{a}}$ & $7.6^{\mathrm{b}}$ \\
\hline & Sprayed & $10.5^{b}$ & $6.7^{\mathrm{b}}$ & $8.0^{\mathrm{a}}$ & $4.5^{b}$ & $6.1^{\mathrm{a}}$ & $6.8^{\mathrm{b}}$ \\
\hline & Forested & $23.8^{\mathrm{a}}$ & $18.3^{a}$ & $13.8^{\mathrm{a}}$ & $11.1^{\mathrm{a}}$ & $8.2^{\mathrm{a}}$ & $15.4^{\mathrm{a}}$ \\
\hline \multirow[t]{3}{*}{ Subalpine fir } & Bracken & $14.9^{\mathrm{a}}$ & $15.1^{a}$ & $13.7^{\mathrm{a}}$ & $13.5^{\mathrm{a}}$ & $11.1^{\mathrm{a}}$ & $12.9^{a}$ \\
\hline & Sprayed & $15.6^{\mathrm{a}}$ & $13.9^{a}$ & $15.5^{\mathrm{a}}$ & $14.3^{\mathrm{a}}$ & $13.9^{a}$ & $15.3^{\mathrm{a}}$ \\
\hline & Forested & $15.7^{\mathrm{a}}$ & $13.7^{\mathrm{a}}$ & $13.5^{\mathrm{a}}$ & $12.9^{a}$ & $11.6^{\mathrm{a}}$ & $13.7^{\mathrm{a}}$ \\
\hline \multirow[t]{3}{*}{ Engelmann spruce } & Bracken & $13.9^{b}$ & $14.0^{\mathrm{a}}$ & $13.3^{\mathrm{a}}$ & $12.7^{\mathrm{a}}$ & $11.2^{\mathrm{a}}$ & $12.9^{\mathrm{a}}$ \\
\hline & Sprayed & $15.4^{\mathrm{a}, \mathrm{b}}$ & $14.8^{\mathrm{a}}$ & $13.0^{\mathrm{a}}$ & $13.3^{\mathrm{a}}$ & $11.2^{\mathrm{a}}$ & $14.2^{\mathrm{a}}$ \\
\hline & Forested & $17.5^{\mathrm{a}}$ & $14.1^{\mathrm{a}}$ & $12.6^{a}$ & $11.3^{\mathrm{b}}$ & $11.5^{\mathrm{a}}$ & $13.5^{\mathrm{a}}$ \\
\hline \multirow[t]{3}{*}{ Douglas-fir } & Bracken & $31.5^{\mathrm{a}}$ & $31.4^{\mathrm{a}}$ & $28.8^{a}$ & $27.5^{\mathrm{a}}$ & $21.9^{b}$ & $30.2^{a}$ \\
\hline & Sprayed & $30.1^{a}$ & $32.0^{\mathrm{a}}$ & $31.9^{a}$ & $27.4^{\mathrm{a}}$ & $25.0^{\mathrm{a}, \mathrm{b}}$ & $32.4^{a}$ \\
\hline & Forested & $33.8^{\mathrm{a}}$ & $29.1^{a}$ & $28.5^{a}$ & $27.7^{\mathrm{a}}$ & $28.5^{\mathrm{a}}$ & $30.1^{a}$ \\
\hline \multirow[t]{3}{*}{ Grand fir } & Bracken & $27.7^{\mathrm{a}}$ & $29.6^{a}$ & $26.3^{a}$ & $26.3^{a}$ & $24.9^{a}$ & $28.3^{a}$ \\
\hline & Sprayed & $29.1^{a}$ & $27.3^{\mathrm{a}}$ & $27.8^{\mathrm{a}}$ & $28.3^{a}$ & $26.2^{a}$ & $29.6^{a}$ \\
\hline & Forested & $27.7^{a}$ & $30.0^{\mathrm{a}}$ & $29.6^{a}$ & $29.9^{a}$ & $27.9^{\mathrm{a}}$ & $30.7^{a}$ \\
\hline
\end{tabular}

the side of the pan extending about $2 \mathrm{~cm}$ above ground level. A hole on the bottom, downhill side of each pan provided drainage. The purpose of the potting mix was to separate the effects of the current year's litter from the effects of the native soil.

Nylon mesh seed packets were prepared to enable recovery of seed after stratification. Packets were $15 \mathrm{~cm}^{2}$ and sewn into quarters to hold 25 seeds of each species. Packets were labeled, enclosed with wire screening to prevent rodent feeding, and placed at the study site on October 4 and 5,1984 . In October, the bracken fronds were brown but standing, and the wet season had not begun.

Six replications of seed packets were placed in each treatment area. Packets placed on native treatment soil were tethered by a wire to a stake driven into the ground. Loose litter was brushed away to ensure seed packets were in contact with the soil surface. Small wires pinned seed packets to the ground.

Six replications of seed packets in potting mix soil were placed in an aluminum pan. Litter removed when burying the pans was replaced on top of the packets. Then standing fronds in bracken treatments were bent over the pans and covered with hardware cloth to hold the litter and seed packets in place.

Seed was overwintered at the site and collected on June 5, 1985. Although the study site was free of snow before June 5, earlier access was prevented by snowdrifts in the roads. Soil and seed packets were transported to
Moscow and stored in a cooler at $2{ }^{\circ} \mathrm{C}$ while seeds were examined and transferred to germination trays.

As an additional check on seed viability, six replications of seed for the four conifer species were placed in germination trays. Seed was stratified for 10 minutes in a solution containing 60 percent distilled water and 40 percent bleach (the bleach contained 5.25 percent sodium hypochlorite), then rinsed for 65 hours in running water-a procedure recommended by Advincula and others (1983). Each germination tray held 25 seeds of one species, the seeds being placed on filter paper and moistened with distilled water. These trays, and those containing seed stratified at the study site, were kept in growth chambers at $30^{\circ} \mathrm{C}$ and 8 hours of light alternated with $20^{\circ} \mathrm{C}$ and 16 hours of darkness.

\section{Results}

Much of the conifer seed germinated at the study site, and radicles had penetrated the nylon mesh and wire screen. Ungerminated seed was transferred to germination trays, but few of these seeds germinated. Molds eventually became a problem, and moldy seed was discarded to prevent contamination of other seed.

Results of seed germination are summarized in table 4 . First, total percentage of germination is shown by species, treatment, and soil type. This figure includes all seed that germinated (radicle length $\geqslant$ seed length). Next is shown the percentage of seed that had germinated but was dead 
Table 4-Seed stratification study: Percentage germination of conifer seed on treatment soil and potting mix by species, treatment, and status. Each figure is the average of six replications of 25 seeds. Within species, treatment, and status, means followed by different letters are significantly different at the 5 percent level using Duncan's multiple range test. For total percent germination, underlining indicates no significant difference between this mean and the mean for the stratified control in the right-hand column

\begin{tabular}{|c|c|c|c|c|c|c|c|c|}
\hline \multirow[b]{3}{*}{ Species } & \multirow[b]{3}{*}{ Status ${ }^{1}$} & \multicolumn{6}{|c|}{ Treatment and soil type } & \multirow{3}{*}{$\begin{array}{c}\text { Stratified } \\
\text { control }\end{array}$} \\
\hline & & \multicolumn{2}{|c|}{$\begin{array}{c}\text { Bracken } \\
\text { glade }\end{array}$} & \multicolumn{2}{|c|}{$\begin{array}{l}\text { Sprayed } \\
\text { bracken }\end{array}$} & \multicolumn{2}{|c|}{ Forested } & \\
\hline & & Soil & Mix & Soil & Mix & Soil & Mix & \\
\hline \multirow[t]{2}{*}{ Subalpine fir } & Total germinated & $77.3^{\mathrm{a}}$ & $80.6^{a}$ & $64.0^{2}$ & $86.8^{2}$ & $8.7^{b}$ & $47.7^{\mathrm{a}}$ & 62.7 \\
\hline & Germinated and dead & $73.3^{a}$ & $1.3^{b}$ & $64.0^{2}$ & $15.4^{b}$ & $2.0^{\mathrm{a}}$ & $1.5^{2}$ & \\
\hline \multirow[t]{2}{*}{ Engelmann spruce } & Total germinated & $14.0^{\mathrm{a}}$ & $16.8^{a}$ & $2.0^{a}$ & $4.0^{\mathrm{a}}$ & $0.0^{2}$ & $10.0^{a}$ & 32.9 \\
\hline & Germinated and dead & $0.0^{2}$ & $0.7^{\mathrm{a}}$ & $0.7^{2}$ & $0.0^{2}$ & $0.0^{2}$ & $1.3^{\mathrm{a}}$ & \\
\hline \multirow[t]{2}{*}{ Douglas-fir } & Total germinated & $46.0^{\circ}$ & ${\underline{86.3^{a}}}^{-}$ & $38.7^{b}$ & $76.6^{a}$ & $4.0^{\circ}$ & $25.6^{\mathrm{a}}$ & 78.7 \\
\hline & Germinated and dead & $35.3^{a}$ & $\overline{0.0^{b}}$ & $28.7^{2}$ & $\overline{0.0^{b}}$ & $0.7^{\mathrm{a}}$ & $0.7^{a}$ & \\
\hline \multirow[t]{2}{*}{ Grand fir } & Total germinated & $66.7^{2}$ & $71.3^{a}$ & $71.3^{a}$ & $81.1^{2}$ & $5.3^{b}$ & $54.3^{a}$ & 38.7 \\
\hline & Germinated and dead & $66.0^{\mathrm{a}}$ & $20.2^{b}$ & $71.3^{a}$ & $33.6^{b}$ & $1.3^{2}$ & $8.9^{a}$ & \\
\hline
\end{tabular}

1Total germinated: average total germination regardless of whether seedlings lived or died. Germinated and dead: average percentage of seeds that were dead when seed packets were opened.

when seed packets were opened. This percentage is for the number of seeds sown, not just those that germinated.

The most noticeable difference in table 4 is the percentage of dead seedlings on the bracken fern soils compared to potting mix soil. Most seed germinating on bracken soil were dead when the seed packets were opened, whereas most seed germinating on potting mix were alive. Ger- minants on both soil types had radicles up to $3 \mathrm{~cm}$ long, displaying considerable germination energy, but seed on native bracken soils died before shedding their seedcoats. Radicles in bracken soils were shriveled and dark brown (fig. 4). Germinants in potting mix treatments shed their seedcoats and radicles extended into the potting mix (fig. 5), although some radicle tips were brown.

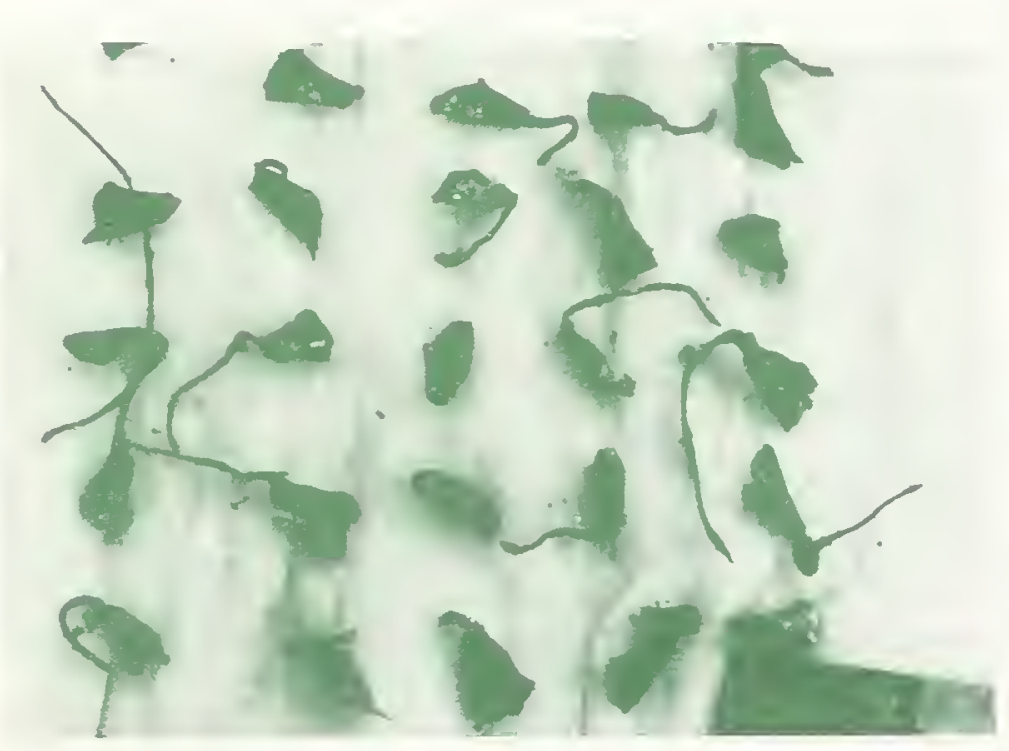

Figure 4-Seed from a seed packet stratified on bracken soil. Seed died after radicle elongation but before shedding seedcoats.

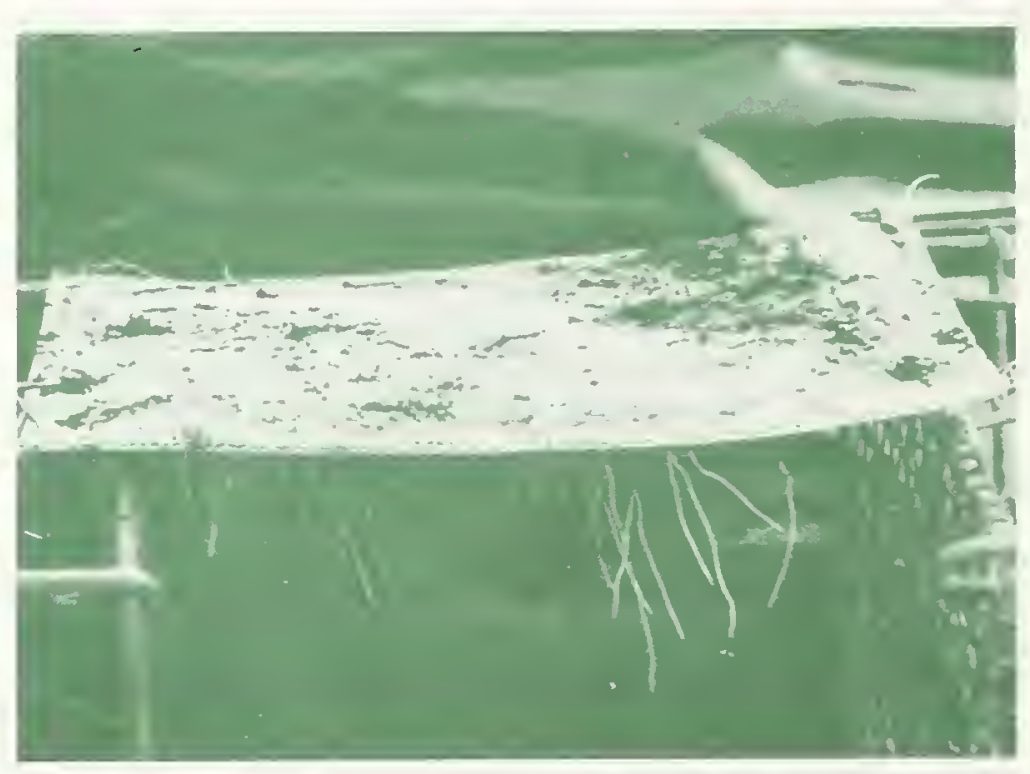

Figure 5-Seed packet from the potting soil portion of the seed stratification study. Note the healthy radicles that have penetrated the mesh seed packet. 
Table 4 also shows that in the native bracken soils, total percentage of germination is not significantly different than germination on potting mix, with the exception of Douglas-fir. When total germination between the two soil types is the same, differences in percentage of seed germinating but dying can be attributed to soil type. Said another way, stratification of seed in bracken environments did not reduce germination, but major differences in survival developed after seed germination. Douglas-fir germination seems to have been affected by stratification because seed overwintered on bracken soil has significantly lower total percentage germination than on potting mix transported to the same site.

Engelmann spruce had very low germination on all treatment and soil types. Because 32.9 percent of spruce seed germinated in the stratified control, we believe most spruce seed was killed (or germination energy reduced) during the overwintering period.

Results from the forested site are inadequate as a control for this study. Conditions under the dense tree overstory are quite different than in the open bracken glades. Fewer seeds germinated in the forested treatment than in any other treatment. Because conifer seed germinated and survived on forest soil in our greenhouse bioassay tests, we feel the loss of seed viability is associated with conditions in the understory and not an inherent problem with the soil.

\section{CONCLUSIONS AND DISCUSSION}

The review of literature showed that bracken fern is a troublesome weed worldwide. It can quickly invade disturbed forests and grazed lands. Increases in bracken occurrence are attributable to human activities. Bracken is well adapted to maintaining dominance because of its unpalatability to browsing, chemical defenses against insects (Cooper-Driver 1976), ability to sprout following disturbance, and production of phytotoxins.

Bracken fern phytotoxins could reduce or eliminate other species in several ways, such as killing seed during stratification, reducing seed germination energy, reduced vigor that predisposes seedlings to other causes of mortality, or the death of plants caused by absorption of phytotoxins. Our studies on bracken fern were conducted to test the allelopathic potential of bracken fern in northern Idaho and to elucidate mechanism(s) that account for bracken dominance.

Tests conducted at our Moscow, ID, greenhouse found some statistically significant reductions in germination and growth attributable to bracken-dominated soil. Tests at a bracken fern glade showed even more striking results in that most seed died when germinated on soil dominated by bracken. The large percentage of seedlings that died helps explain the nearly total exclusion of conifers from bracken glades in northern Idaho.

Based on the results of this research, we feel an important mechanism limiting establishment of conifers in bracken glades of northern Idaho is death of germinants as the radicle penetrates the upper surface of the soil. Death probably results when the germinant absorbs phytotoxins that have accumulated in the soil over a number of years.
We hypothesize that phytotoxins are concentrated near the soil surface. This follows from finding reduced germination and growth in the greenhouse bioassay tests only in tests having bracken glade soil from the 0 - to 5 -cm depth. Even for the 0 - to 5-cm depth, more seed survived in the greenhouse test compared to seed germinated at the study site. Mixing of the soil in the 0 - to 5 -cm depth may have diluted the phytotoxin, indicating that if a phytotoxic layer is present, it is thin. In addition, radicle lengths of dead seed in the seed stratification study were less than $3 \mathrm{~cm}$.

Other investigators have reported that allelopathic effects are greatest near the soil surface. Gliessman and Muller (1978) collected raindrip from bracken fronds under field conditions and showed allelopathic effects using bioassay tests. They hypothesized that toxins were being concentrated in the upper soil layers where they remain even with heavy rainfall. Horsley (1977) thought that toxins from three species he investigated may be bound to the soil complex and at least 1 year is necessary for toxic plant residues to be neutralized, destroyed, or leached. Muller (1966), working in California chaparral, found that herbs were able to become established following a fire or after a layer of soil $5 \mathrm{~cm}$ thick was removed.

Discussion of bracken fern communities in northern Idaho would be incomplete without considering interactions with pocket gophers. The role of gophers in bracken communities is seldom mentioned in the literature. Gophers feed on forbs, grasses, shrubs, conifers, seeds, and just about any vegetation not poisonous (Teipner and others 1983). We do not know if pocket gophers feed on bracken, but few other species grow in these bracken glades where gopher populations are high.

Gophers deposit subsurface soil above ground in mounds and casts. This buries existing vegetation and, over time, would create a mosaic of microsites differing in successional status. These microsites could account for the presence of forbs, grasses, and sedges which, in turn, supply food for the gophers. These species could become established on fresh mounds, eventually dying out as bracken phytotoxins again accumulate.

Shrubs and conifers could also become established on gopher mounds. Tevis (1956) noted that an abundant red fir (Abies magnifica) cone crop in northern California resulted in good reproduction on ground bared by pocket gophers. (Interestingly, he noted that gopher-bared ground in nonbracken areas had "abundant" seedlings whereas seedlings on gopher-bared ground in bracken areas were "moderately common.") Seed predation by gophers and mice could account for loss of some shrub and conifer seeds, but this is unlikely to be the whole story.

An additional explanation for the lack of woody species in northern Idaho bracken glades concerns decomposition of bracken fronds under the snow. Even the casual observer is impressed with the large amount of bracken frond biomass at the Eagle Point study site. Znerold (1979) calculated frond density at 286,300 stems/ha and frond ovendry weight at $3,900 \mathrm{~kg} / \mathrm{ha}$. Each autumn fronds die, fall over, and are pressed to the earth by snow. In the spring, little evidence of old bracken fronds exists except for portions of the thick petioles that are not totally decomposed. A great deal of decomposition must take 
place under the snow. Any plants crushed to the ground with bracken fronds might perish as a direct or indirect result of bracken decomposition, including succulent conifers and shrubs regenerating on pocket gopher mounds.

This possibility is speculative (and needs to be tested) but seems plausible because the few species associated with bracken fern in these glades are herbaceous (annual, biennial, or perennial plants that die back to the ground at the end of the growing season). Bracken appears to have dominated these glades for hundreds of years, and there is little evidence of succession to woody species. We have observed that shrub and conifer seed are cast into the glade. Some species of seed may be killed during stratification or the germination energy reduced below the level needed for survival. If seed does germinate, it can die as a result of absorbing phytotoxins. Seedlings surviving all of the above would then be subjected to smothering by bracken fronds and decomposition under the snow. These competitive mechanisms severely limit the establishment of woody species in bracken-dominated areas of northern Idaho.

\section{RECOMMENDATIONS}

The exploratory studies reported in this paper were designed to increase our understanding of bracken fern. Based on these results and the literature review, a list of recommendations was compiled. Additional research is needed to find answers to specific reforestation questions. For now, it should be remembered that bracken is a problem weed throughout the world, no economical solutions for its control have been found, and prevention of problems with bracken is the preferred alternative. These recommendations apply to reforestation efforts in areas where bracken has successfully invaded previously harvested stands and where bracken is present in and around stands scheduled for harvesting.

1. Recognize that allelopathy can be a major consideration when developing a silvicultural prescription. Ignoring this constraint negates investments of time and money in reforestation efforts. However, allelopathy is not a magical answer to reforestation failures.

2. Plan to regenerate stands quickly following harvest. We have found bracken rhizomes in dense forest stands adjacent to bracken glades and bracken-dominated cutover stands. Rhizome expansion coupled with colonization by spores can quickly increase bracken dominance.

3. Keep site preparation to a minimum. Hot burns or excessive scarification encourage invasion of bracken fern via spores. See Stickney (1986) for examples of bracken invasion following a severe fire in northern Idaho. Repeated burns unduly favor bracken because fires do not kill the rhizomes, which readily resprout.

4. Do not rely on natural regeneration. Plant trees as soon after harvest as possible and protect them from pocket gophers and grazing animals. Prompt planting will help ensure that trees are established before gopher populations and bracken cover build up. Planted trees should survive well if protected, but growth rates will be reduced where bracken cover is thick.
5. Exclude natural bracken glades within the stand from land to be reforested. Few, if any, trees have grown on these sites in the past. Including these areas gives a false picture of seedling density and percentage of stocked plots. Naturally occurring bracken glades are hundreds of years old and appear to be the climax vegetation. These glades are worthy of consideration as a distinct habitat type.

\section{REFERENCES}

Acsai, J.; Largent, D. L. 1983. Ectomycorrhizae of selected conifers growing in sites which support dense growth of bracken fern. Mycotaxon. 16: 509-518.

Advincula, B. A.; Woo, J. Y.; Partridge, A. D. 1983. A method for germination of western white pine seeds. Unpublished paper presented at: Western Forestry and Conservation Association Conference; 1983 December 12-14; Portland, OR. 4 p.

Bohm, B. A.; Tryon, R. M. 1967. Phenolic compounds in ferns. I. A survey of some ferns for cinnamic acid and benzoic acid derivatives. Canadian Journal of Botany. 45: 585-593.

Boyd, R. J.; Znerold, R. M. [In preparation]. The effects of bracken fern control with asulam on the subsequent performance of planted conifers in northern Idaho. Moscow, ID: U.S. Department of Agriculture, Forest Service, Intermountain Research Station.

Braid, K. W. 1959. Bracken: a review of the literature. Publication 3. England: Commonwealth Bureau of Pastures and Field Crops. 69 p. Mimeo.

Brown, R. T. 1967. Influence of naturally occurring compounds on germination and growth of jack pine. Ecology. 48: 542-546.

Cody, W. J.; Crompton, C. W. 1975. The biology of Canadian weeds. 15. Pteridium aquilinum (L.) Kuhn. Canadian Journal of Plant Science. 55: 1059-1072.

Conway, E. 1952. Bracken - the problem plant, a review of recent conclusions about its spread and dominance. Scottish Agriculture. 31: 181-184.

Cooper-Driver, G. 1976. Chemotaxonomy and phytochemical ecology of bracken. Linnean Society Botanical Journal. 73: 35-46.

Cooper, S. V.; Neiman, K. E.; Steele, R.; Roberts, D. W. 1987. Forest habitat types of northern Idaho: a second approximation. Gen. Tech. Rep. INT-236. Ogden, UT: U.S. Department of Agriculture, Forest Service, Intermountain Research Station. 135 p.

DeBell, D. S. 1970. Phytotoxins, new problems in forestry? Journal of Forestry. 68: 335-337.

del Moral, R.; Cates, R. G. 1971. Allelopathic potential of the dominant vegetation of western Washington. Ecology. 52: 1030-1037.

Dimock, E. J., II. 1964. Supplemental treatments to aid planted Douglas-fir in dense bracken fern. Res. Note PNW-11. Portland, OR: U.S. Department of Agriculture, Forest Service, Pacific Northwest Forest and Range Experiment Station. $10 \mathrm{p}$.

Evans, I. A. 1976. Relationship between bracken and cancer. Linnean Society Botanical Journal. 73: 105-112. 
Fisher, R. F. 1978. Juglone inhibits pine growth under certain moisture regimes. Soil Science Society of America Journal. 42: 801-803.

Fisher, R. F. 1979. Allelopathy. In: Horsfall, J.G.; Cowling, E. B., eds. Plant disease: an advanced treatise. Vol. IV. New York: Academic Press: 313-330.

Glass, A. D. M.; Bohm, B. A. 1969. The accumulation of cinnamic and benzoic acid derivatives in Pteridium aquilinum and Athyrium filix-femina. Phytochemistry. 8: 371-377.

Gliessman, S. R. 1976. Allelopathy in a broad spectrum of environments as illustrated by bracken. Linnean Society Botanical Journal. 73: 95-104.

Gliessman, S. R.; Muller, C. H. 1972. The phytotoxic potential of bracken, Pteridium aquilinum (L.) Kuhn. Madroño. 21: 299-304.

Gliessman, S. R.; Muller, C. H. 1978. The allelopathic mechanisms of dominance in bracken (Pteridium aquilinum) in southern California. Journal of Chemical Ecology. 4: 337-362.

Hirono, I. 1981. Natural carcinogenic products of plant origin. CRC Critical Reviews in Toxicology. 8(3): 235-277.

Hirono, I.; Shibuya, C.; Shimizu, M.; Fushimi, K. 1972. Carcinogenic activity of processed bracken used as human food. Journal of the National Cancer Institute. 48: 1245-1250.

Horsley, S. B. 1977. Allelopathic inhibition of black cherry by fern, grass, goldenrod, and aster. Canadian Journal of Forest Research. 7: 205-216.

Martin, D. J. 1976. Control of bracken. Linnean Society Botanical Journal. 73: 241-246.

Muller, C. H. 1966. The role of chemical inhibition (allelopathy) in vegetation composition. Bulletin of the Torrey Botanical Club. 93: 332-351.

Page. C. N. 1982. The history and spread of bracken in Britain. Proceedings of the Royal Society of Edinburgh. 81B: 3-10.

Pamukcu, A. M.; Ertürk, E.; Yalciner, S.; Milli, U.; Bryan, G. T. 1978. Carcinogenic and mutagenic activities of milk from cows fed bracken fern (Pteridium aquilinum). Cancer Research. 38: 1556-1560.

Preest, D. S. 1975. Review of and observation on current methods of bracken control in forestry. Proceedings of the 28th New Zealand Weed Control Conference: 43-48.

Rice, E. L. 1979. Allelopathy-an update. The Botanical Review. 45: 15-109.

Rice, E. L. 1984. Allelopathy. Orlando, FL: Academic Press. $422 \mathrm{p}$.

Rietveld, W. J.; Schlesinger, R. C.; Kessler, K. J. 1983. Allelopathic effects of black walnut on European black alder coplanted as a nurse species. Journal of Chemical Ecology. 9: 1119-1133.

Rose, S. L.; Perry, D. A.; Pilz, D.; Schoeneberger, M. M. 1983. Allelopathic effects of litter on the growth and colonization of mycorrhizal fungi. Journal of Chemical Ecology. 9: 1153-1162.

Rymer, L. 1976. The history and ethnobotany of bracken. Linnean Society Botanical Journal. 73: 151-176.

Stewart, R. E. 1975. Allelopathic potential of western bracken. Ecology. 1: 161-169.
Stickney, P. F. 1986. First decade plant succession following the Sundance Forest Fire, northern Idaho. Gen.

Tech. Rep. INT-197. Ogden, UT: U.S. Department of Agriculture, Forest Service, Intermountain Research Station. 26 p.

Taylor, J. A. 1985. Bracken encroachment rates in Britain. Soil Use and Management. 1: 53-56.

Teipner, C. L.; Garton, E. O.; Nelson, L., Jr. 1983. Pocket gophers in forest ecosystems. Gen. Tech. Rep. INT-154. Ogden, UT: U.S. Department of Agriculture, Forest Service, Intermountain Forest and Range Experiment Station. 53 p.

Tevis, L., Jr. 1956. Pocket gophers and seedlings of red fir. Ecology. 37: 379-381.

Whitehead, D. C. 1964. Identification of p-hydroxybenzoic, vanillic, $p$-coumaric and ferulic acids in soils. Nature. 202: 417-418.

Whittaker, R. H.; Feeny, P. P. 1971. Allelochemics: chemical interactions between species. Science. 171: 757-770.

Wilson, D.; Coyner, J.; Deckert, T. 1983. Land system inventory of the Clearwater National Forest. Orofino, ID: Clearwater National Forest. 398 p. First review draft.

Znerold, R. M. 1979. Western bracken control with asulam. Pullman, WA: Washington State University. $36 \mathrm{p}$. Thesis. 


\section{PESTICIDE PRECAUTIONARY STATEMENT}

This publication reports research involving pesticides. It does not contain recommendations for their use, nor does it imply that the uses discussed here have been registered. All uses of pesticides must be registered by appropriate State and/or Federal agencies before they can be recommended.

CAUTION: Pesticides can be injurious to humans, domestic animals, desirable plants, and fish or other wildlife-if they are not handled or applied properly. Use all pesticides selectively and carefully. Follow recommended practices for the disposal of surplus pesticides and pesticide containers.

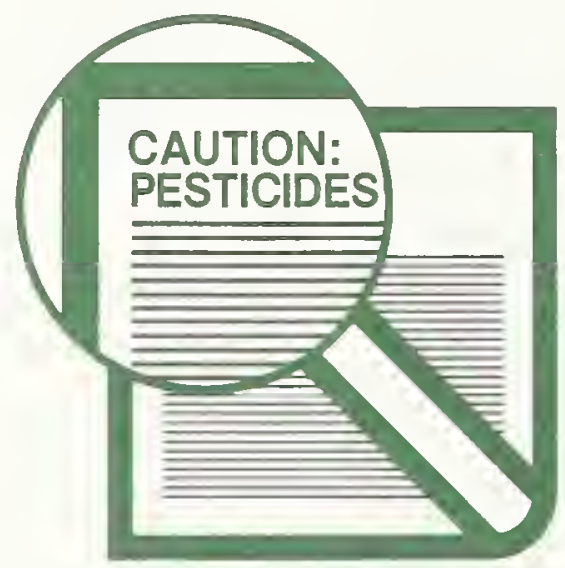


Ferguson, Dennis E.; Boyd, Raymond J. 1988. Bracken fern inhibition of conifer regeneration in northern Idaho. Res. Pap. INT-388. Ogden, UT: U.S. Department of Agriculture, Forest Service, Intermountain Research Station. 11 p.

Investigations on the allelopathic potential of bracken fern in northern Idaho were conducted to gain an understanding of the mechanism(s) associated with regeneration failures. Average growth and green top weight of conifers planted in potting soil were about 1.8 and 1.6 times greater than those planted in soil from bracken glades.

Greenhouse tests showed little reduction in germination of conifer and shrub seeds on soil from bracken glades. Further germination tests of conifer seeds in bracken glades showed that seeds germinated but died before shedding their seedcoats. The percentage of dead seed helps explain the virtual exclusion of conifers from bracken fern glades in northern Idaho.

KEYWORDS: Pteridium aquilinum, allelopathy, phytotoxins, competition 


\section{INTERMOUNTAIN RESEARCH STATION}

The Intermountain Research Station provides scientific knowledge and technology to improve management, protection, and use of the forests and rangelands of the Intermountain West. Research is designed to meet the needs of National Forest managers, Federal and State agencies, industry, academic institutions, public and private organizations, and individuals. Results of research are made available through publications, symposia, workshops, training sessions, and personal contacts.

The Intermountain Research Station territory includes Montana, Idaho, Utah, Nevada, and western Wyoming. Eighty-five percent of the lands in the Station area, about 231 million acres, are classified as forest or rangeland. They include grasslands, deserts, shrublands, alpine areas, and forests. They provide fiber for forest industries, minerals and fossil fuels for energy and industrial development, water for domestic and industrial consumption, forage for livestock and wildlife, and recreation opportunities for millions of visitors.

Several Station units conduct research in additional western States, or have missions that are national or international in scope.

Station laboratories are located in:

Boise, Idaho

Bozeman, Montana (in cooperation with Montana State University)

Logan, Utah (in cooperation with Utah State University)

Missoula, Montana (in cooperation with the University of Montana)

Moscow, Idaho (in cooperation with the University of Idaho)

Ogden, Utah

Provo, Utah (in cooperation with Brigham Young University)

Reno, Nevada (in cooperation with the University of Nevada)

USDA policy prohibits discrimination because of race, color, national origin, sex, age, religion, or handicapping condition. Any person who believes he or she has been discriminated against in any USDA-related activity should immediately contact the Secretary of Agriculture, Washington, DC 20250. 